\title{
Melalui survei kepuasan masyarakat: tingkatkan kualitas layanan pendidikan
}

\author{
Mawar Sukma Sinaga $^{a 1}$, Adji Suradji Muhammad ${ }^{\text {b2 }}$ \\ aProgram Studi Ilmu Administrasi Negara Universitas Maritim Raja Ali Haji, Kelurahan Air Raja, \\ Tanjungpinang dan 29122 \\ ${ }^{b}$ Program Studi Ilmu Administrasi Negara, Universitas Maritim Raja Ali Haji, Perumahan Mutiara Bintan, \\ Tanjungpinang dan 29125 \\ 1'mawarssinaga@gmail.com, ${ }^{2}$ suradji@umrah.ac.id
}

\section{INFO ARTIKEL}

\section{Riwayat Artikel:}

Diterima: 30-04-2020

Disetujui: $18-07-2020$

\section{Kata Kunci:}

1. Survei Kepuasan Masyarakat

2. Kualitas Pelayanan

3. Layanan Pendidikan

\begin{abstract}
ABSTRAK
Abstrak: Pemerintah memiliki tugas utama yaitu mencerdaskan kehidupan bangsa merupakan salah satu tugas utama pemerintah. sebagaimana tertuang dalam "Pembukaan Undang-Undang Dasar 1945", diartikan secara mendalam dan menyeluruh bahwa melalui pendidikan setiap warga dapat meningkatkan taraf kehidupannya dari tingkat terendah hingga ketingkat pencapaian tertinggi. Survei Kepuasan Masyarakat merupakan media untuk mengetahui persepsi masyarakat terhadap kualitas layanan pemerintah dalam bidang Pendidikan. Penelitian ini merupakan deskriptif kuantitatif yang berpedoman pada Peraturan Menteri Pendayagunaan Aparatur Negara dan Reformasi Birokrasi Nomor 14 Tahun 2017 Tentang Pedoman Penyusunan Survei Kepuasan Masyarakat Unit Penyelenggara Pelayanan Publik yang menggunakan metode survei dengan pengukuran skala Likert. Responden dalam penelitian ini merupakan pengguna pelayanan publik dalam bidang pendidikan di Kabupaten Bintan. Melalui survei ini diketahui bahwa nilai kesenjangan pelayanan yang diberikan dan ekspektasi penerima layanan dalam Bidang Layanan Pendidikan yang diselenggaran Pemerintah Kabupaten Bintan secara keseluruhan unsur yang dinilai memperoleh klasifikasi baik dengan nilai GAP berada di kisaran 0,80,99 ,
\end{abstract}

\begin{abstract}
The government has the main task of educating the life of the nation is one of the main tasks of the government. as stated in the "Opening of the 1945 Constitution", is interpreted in-depth and comprehensively that through education every citizen can improve his standard of living from the lowest level to the highest level of achievement. The Community Satisfaction Survey is a media to find out people's perceptions of the quality of government services in the field of Education. This research is a quantitative descriptive based on the Regulation of the Minister of Administrative Reform and Bureaucratic Reform No. 14 of 2017 Concerning Guidelines for the Compilation of Public Satisfaction Unit of Public Service Providers using survey methods with Likert scale measurement. Respondents in this study are users of public services in the field of education in the Bintan Regency. Through this survey, it is known that the value of service gaps and expectations of service recipients in the Education Service Sector held by the Bintan Regency Government as a whole is considered to have good classification with GAP values in the range of 0.8 to 0.99 .
\end{abstract}

\section{LATAR BELAKANG}

1. Kepuasan Masyarakat

Tuntutan terhadap kualitas pelayanan publik merupakan topik perhatian yang terus meningkat. Mampu memuaskan pelanggan merupakan pelayanan yang terbaik. Memuaskan pelayanan merupakan keinginan setiap organisasi ataupun perusahaan dan hal penting bagi kepercayaan pelanggan/masyarakat[1]

Pengajuan tuntutan, keinginan dan aspirasi menjadi bentuk kesadaran masyarakat sebagai warga negara dalam kehidupan bermasyarakat, berbangsa dan bernegara untuk mengontrol apa yang dilakukan pemerintah[2]. 
Pendidikan memiliki peran penting dalam kemajuan suatu bangsa. Setiap anak berhak untuk mengenyam pendidikan guna menjalani kehidupan yang lebih baik dan berperan untuk memajukan bangsa nantinya. Pembangunan pendidikan di Indonesia berpegang pada salah satu tujuan bangsa Indonesia di UUD 1945 alenia ke-4 yaitu mencerdaskan kehidupan bangsa[3].

Maka merupakan kewajiban bagi pemerintah pusat dan daerah dalam meningkatkan kualitas pelayanan bidang pendidikan. Yangmana pihak pemerintah lebih memperhatikan pelayanan publik tersebut karena ini berhubungan dengan kepuasan orang tua dalam pemberian pendidikan kepada anaknya, dengan harapan mendapatkan kualitas pendidikan dan fasilitas yang mendukung bagi anaknya yang bersekolah[4].

Pendidikan di Indonesia dilaksanakan melalui jalur, level, dan jenis pendidikan. Jalulr pendidikan adalah media dimana siswa membangun potensi mereka dalam suatu proses yang sesuai dengan tujuan pendidikan. instruktif. Ada tiga jalur pendidikan yaitu, formal, non-formal dan kasual. Pendidikan formal adalah jalur pengajaran yang terorganisir dan berlapis yang terdiri dari pendidikan dasar, pengajaran tambahan dan pendidikan lanjutan. Jika pendidikan non-formal adalah jalur pendidikan di luar pendidikan formal yang dapat dilaksanakan secara terorganisir dan berlapis[5].

Penelitian ini dilakukan di layanan pendidikan Kabupaten Bintan. Sebagai kabupaten dengan pulau-pulau terluar, menciptakan kualitas pendidikan yang terus meningkat menjadi tantangan bagi pemerintah daerah agar bisa memberikan layanan yang sama seperti daerah lain. Terwujudnya Kabupaten Bintan yang madani dan sejahtera melalui pencapaian Bintan Gemilang 2025 merupakan Visi dan Misi Kabupaten Bintan Kabupaten Bintan 2016-2021 dari visi tersebut salah satu misi yang diturunkan adalah meningkatkan kualitas pendidikan agar yang dapat bersaing dengan dunia[6]. Menyadari hal tersebut untuk mencapaian visi diperlukan mengukur kepuasan masyarakat pengguna layanan pendidikan Kabupaten Bintan untuk meningkatkan kualitas layanan pendidikan.
Penelitian ini ingin memberikan gambaran, faktor-faktor yang mempengaruhi kepuasan masyarakat terhadap pelayanan pendidikan di Kabupaten Bintan dan diharapkan dapat menjadi tolak ukur untuk menilai kualitas pelayanan pendidikan serta memberikan masukan kepada pemerintah daerah khususnya pemerintah Kabupaten Bintan dalam melakukan perbaikan kualitas pelayanan publik sesuai dengan harapan masyarakat.

\section{TINJAUAN PUSTAKA}

1. Kepuasan Masyarakat

Menurut Wahdiayanto, Pelayanan adalah suatu yang tidak jasmaniah (tidak dapat diraba) dan melibatkan upaya manusia (karyawan) atau instrumen lain yang disediakan oleh organisasi penyelenggara pelayanan[7]. Kepuasan masyarakat merupakan hal penting dalam pelaksanaan pelayanan pelayanan publik (public service) [7]. Desakan pelaksanaan pemerintahan yang baik (good governance), memperngaruhi pula desakan masyarakat terhadap pelayanan publik yang berkualitas dan sesuai dengan harapan serta kebutuhan masyarakat. Untuk itu, menjadi suatu keharusan bagi aparatur negara sebagai pelayan masyarakat yang mengupayakan kepuasan masyarakat.

2. Kualitas Pelayanan

Kualitas layanan dipahami sebagai keseimbangan antara kepuasan dan harapan dalam hubungan timbal balik antara pelanggan dan organisasi dalam memenuhi kebutuhan mereka[8]. Kualitas layanan yang terus membaik menandakan bahwa kehidupan masyarakat, yang artinya bahwa semakin berkurangnya hambatan dalam melakukan aktifitas sehari-hari. Menurut Berry dalam Concepción, mengukur kualitas layanan adalah tugas yang kompleks, dan berbagai strategi telah dirumuskan untuk memfasilitasi pengukurannya yaitu bukti fisik, keandalan, daya tanggap, jaminan, dan empati [8].

Agar pelaksanaan pelayanan pendidikan lebih berkualitas, sesuai dengan tujuan yang diinginkan, diperlukan pengukuran sejauhmana kinerja kualitas pelayanan. Kualitas layanan dipahami sebagai 
keseimbangan antara kepuasan dan harapan dalam hubungan timbal balik antara pelanggan dan organisasi dalam memenuhi kebutuhan mereka[8]. Kualitas pelayanan publik merupakan dalam penyelenggaraan pemerintahan yang baik (good government), harus dilaksanakan di pemerintah pusat dan pemerintah daerah. Kualitas layanan yang terus membaik menandakan bahwa kehidupan masyarakat, yang artinya bahwa semakin berkurangnya hambatan dalam melakukan aktifitas sehari-hari. Menurut Berry dalam Concepción, mengukur kualitas layanan adalah tugas yang kompleks, dan berbagai strategi telah dirumuskan untuk memfasilitasi pengukurannya yaitu bukti fisik, keandalan, daya tanggap, jaminan, dan empati[8].

Untuk mengetahui kualitas pelayanan publik digunakan indikator-indikator untuk mengukur kinerja pelayanan publik. Menurut Salim dan Woodward, untuk menilai kinerja pelayanan umum menggunakan empat tolak ukur yang terdiri dari economy, efficiency, effectiveness, dan persamaan layanan[9]. Aspek ekonomi, dilihat sebagai strategi dalam memanfaatkan sumber daya seminimal mungkin dalam proses penyelenggaraan kegiatan pelayanan public. Aspek efisiensi, tercapainya kondisi proporsional antara input dan output dengan memberikan layanan berkualitas dengan sumber daya minimum dalam menyediakan layanan[10]. Aspek efektivitas, tercapainya pemenuhan tujuan atau target yang telah ditetapkan dan aspek persamaan pelayanan (keadilan) sebagai ukuran untuk menilai seberapa jauh mendapatkan pelayanan.

Sedangkan dalam Peraturan Menteri Pendayagunaan Aparatur Negara Dan Reformasi Birokrasi Republik Indonesia Nomor 14 Tahun 2017 Tentang Pedoman Penyusunan Survei Kepuasan Masyarakat Unit Penyelenggara Pelayanan Publik, terdapat 9 unsur dalam menilai kinerja unit pelayanan publik meliputi:

\section{Persyaratan}

Persyaratan adalah kondisi yang harus dipenuhi dalam mengurus suatu jenis pelayanan, baik persyaratan teknis maupun administratif.

2. Sistem, Mekanisme, dan Prosedur

Prosedur adalah tata cara standar pelayanan untuk pemberi dan penerima layanan.
3. Waktu Penyelesaian.

Waktu Penyelesaian adalah tempo yang diperlukan untuk menyelesaikan seluruh proses layanan yang telah disiapkan pada setiap jenis pelayanan.

4. Biaya/Tarif

Biaya/Tarif adalah beban yang diberikan penerima layanan dalam mengurus dan/atau memperoleh pelayanan kepada pelaksana yang ditetapkan berdasarkan kesepakatan antara penyelenggara dan masyarakat.

5. Produk Spesifikasi Jenis Pelayanan

Produk spesifikasi jenis pelayanan adalah hasil pelayanan yang telah telah ditetapkan sesuai dengan spesifikasi layanan.

6. Kompetensi Pelaksana

Kompetensi Pelaksana adalah kapabilitas yang layak bagi petugas meliputi pengetahuan, kemampuan, keterampilan, dan pengalaman.

7. Perilaku Pelaksana

Perilaku Pelaksana adalah sikap petugas dalam memberikan pelayanan.

8. Penanganan Pengaduan, Saran dan Masukan

Penanganan pengaduan, saran dan masukan, adalah prosedur pelaksanaan penanganan dan tindak lanjut terhadap pengaduan dari penerima layanan.

9. Sarana dan prasarana

Sarana adalah segala sesuatu yang dapat dimanfaatkan dalam mencapai tujuan dan sasaran. Sedangkan prasarana adalah segala sesuatu yang merupakan penunjang yang mendukung terselenggaranya suatu proses pelayanan (usaha, pengembangan, proyek). Sarana digunakan untuk benda bergerak (komputer, mesin) dan prasarana untuk benda tidak bergerak (bangunan)[11].

\section{METODE PENELITIAN}

Penelitian ini menggunakan kuantitatif deskriptif dan menggunakan metode survei dengan pengukuran skala Likert. Djali menjelaskan bahwa skala Likert adalah skala yang dapat dipergunakan untuk mengukur sikap, pendapat, dan kesan seseorang atau kumpulan induvidu tentang suatu gejala atau fenomena[12]. 
Populasi penelitian ini adalah masyarakat yang memperoleh layanan satu tahun terakhir di Kabupaten Bintan. Sedangkan sampel ditentukan menggunakan table Krejcie and Morgan sebagaimana Peraturan Menteri Pendayagunaan Aparatur Negara dan Reformasi Birokrasi Nomor 14 Tahun 2017 Tentang Pedoman Penyusunan Survei Kepuasan Masyarakat Unit Penyelenggara Pelayanan Publik dimana populasi sampai dengan 1.000.000 dengan jumlah sampel 384 orang

Data dalam penelitian ini berasal dari data primer dan data sekunder. Data primer yang berasal dari hasil survei dengan menggunakan kuesioner responden sebagai pengguna pelayanan publik dalam Bidang Pendidikan di Kabupaten Bintan. Sedangkan data sekunder berupa laporan, peraturan perundangan dan standar operasional prosedur yang digunakan oleh Dinas Pendidikan Kabupaten Bintan.

Analisis Survei Kepuasan Masyarakat diuji dengan 9 (Sembilan) unsur atau indikator yang dikaji yang mengacu pada Peraturan Menteri Pendayagunaan Aparatur Negara dan Reformasi Birokrasi Nomor 14 Tahun 2017 Tentang Pedoman Penyusunan Survei Kepuasan Masyarakat Unit Penyelenggara Pelayanan Publik terdapat. Pengolahan data masing-masing metode Survei kepuasan masyarakat dilakukan dengan langkahlangkah sebagai berikut:

1) Menggunakan Pengukuran Skala Likert dari setiap unsur pertanyaan dalam survei. Masing- masing unsur diberi nilai persepsi 1 sampai dengan nilai persepsi 4 dengan penjelasan sebagai berikut;

a. Sangat Tidak Setuju dengan nilai persepsi 1 ,

b. Tidak Setuju dengan nilai persepsi 2,

c. Setuju dengan nilai persepsi 3, dan

d. Sangat Setuju dengan nilai persepsi 4.

2) Membuat Nilai Tertimbang. Nilai Tertimbang dihitung dengan menggunakan "nilai rata-rata tertimbang" dari masing-masing unsur pelayanan yang setiap unsur pelayanan memiliki penimbang yang sama. Nilai penimbang ditetapkan dengan rumus, sebagai berikut:

Bobot nilai rata - rata tertimbang

$$
=\frac{\text { jumlah bobot }}{\text { jumlah unsur }}=\frac{1}{9}=0,11
$$

3) Menentukan nilai SKM. Untuk memperoleh nilai SKM dari unit pelayanan digunakan pendekatan nilai rata-rata tertimbang dengan rumus sebagai berikut;

$S K M=\frac{\text { Total dari Nilai Persepsi Per Unsur }}{\text { Total Unsur yang terisi }} \times$ Nilai perimbang

Untuk memudahkan interpretasi penilaian SKM yaitu antara $25-100$, maka hasil penilaian tersebut diatas dikonversikan dengan nilai dasar 25, dengan rumus sebagai berikut:

SKM Unit Pelayanan $\times 25$

Hasil perhitungan tersebut diatas dikategorikan sebagai berikut:

TABEL 1

SKALA NILAI PERSEPSI, NILAI INTERVAL, NILAI INTERVAL KONVERSI, MUTU PELAYANAN DAN KINERJA UNIT PELAYANAN

\begin{tabular}{c|l|c|c|c}
\hline $\begin{array}{c}\text { Nilai } \\
\text { Persepsi }\end{array}$ & Nilai Interval (NI) & $\begin{array}{c}\text { Nilai Interval } \\
\text { Konversi (NIK) }\end{array}$ & $\begin{array}{c}\text { Mutu } \\
\text { Pelayanan (x) }\end{array}$ & $\begin{array}{c}\text { Kinerja Unit } \\
\text { Pelayanan }(\mathbf{y})\end{array}$ \\
\hline$(1)$ & $(2)$ & $(3)$ & $(4)$ & $(5)$ \\
\hline 1 & $1,00-2,5996$ & $25,00-64,99$ & D & Tidak Baik \\
\hline 2 & $2,60-3,064$ & $65,00-76,60$ & C & Kurang Baik \\
\hline 3 & $3,0644-3,532$ & $76,61-88,30$ & B & Baik \\
\hline 4 & $3,5324-4,00$ & $88,31-100,00$ & A & Sangat Baik \\
\hline
\end{tabular}




\section{Pembahasan}

\section{Karakteristik Responden}

Deskripsi karakteristik umum responden adalah masyarakat Kabupaten Bintan yang memperoleh layanan pendidikan setahun terakhir, terdiri atas usia, jenis kelamin, tingkat pendidikan, jenis pekerjaan dan layanan yang diterima.

Analisis karakteristik dalam gambar 1, responden dalam survei kepuasaan masyarakat ini menunjukkan bahwa usia responden cukup bervariasi. Responden yang menerima layanan pendidikan (memiliki anak usia sekolah SD/SMP) paling banyak $39,32 \%$ berusia $31-40$ tahun dan terbanyak kedua yaitu sebesar $34,64 \%$ adalah usia 41-50 tahun.

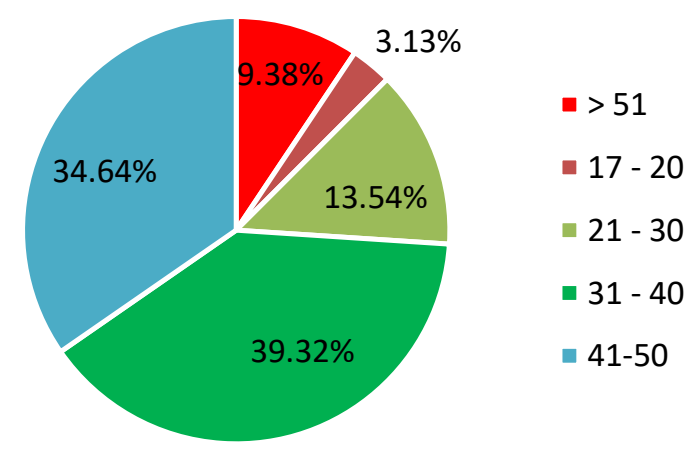

\section{Gambar 1. Karekteristik Responden Berdasarkan Kelompok Umur}

Dalam penelitian ini responden yang menerima layanan pendidikan mayoritas berjenis kelamin lakilaki sebesar 55,73\% dan resnponden dengan jenis kemalin perempuan sebesar $44,27 \%$ sebagaimana dalam gambar 2 dibawah ini.

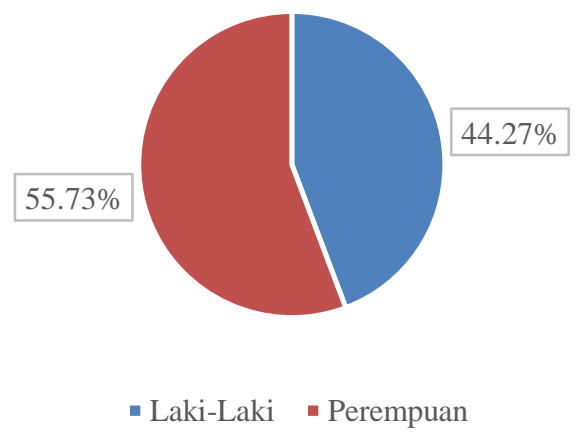

Gambar 2. Karekteristik Responden Berdasarkan Jenis Kelamin

Dalam penelitian ini responden yang mendapatkan layanan pendidikan paling banyak berlatarbelakang pendidikan SMA sebesar 38,28\% dan diikuti oleh responden dengan tingkat pendidikan SD sebesar $31,25 \%$ sebagaimana digambarkan grafik 3 dibawah ini

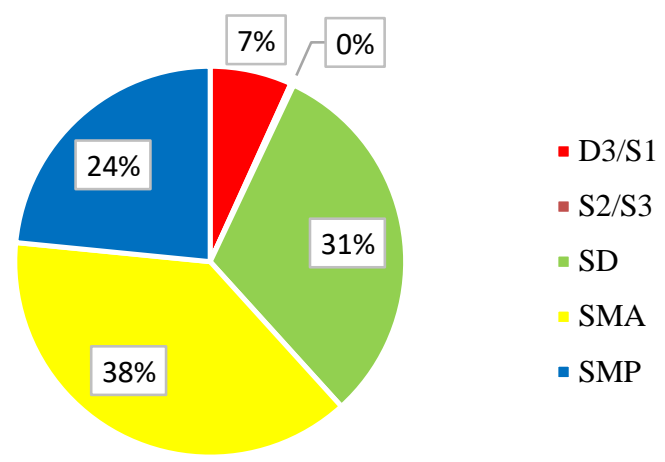

Gambar 3. Karakteristik Responden Berdasarkan Pendidikan Sumber: Data diolah 2018

Responden yang menerima layanan bidang pendidikan 67, 97 diluar profesi PNS/TNI/POLRI, pegawai swasta, pedagang, maupun wiraswasta dan diikuti oleh responden dengan latar belakang swasta $12,76 \%$. Sebagaimana digambarkan pada grafik dibawah ini

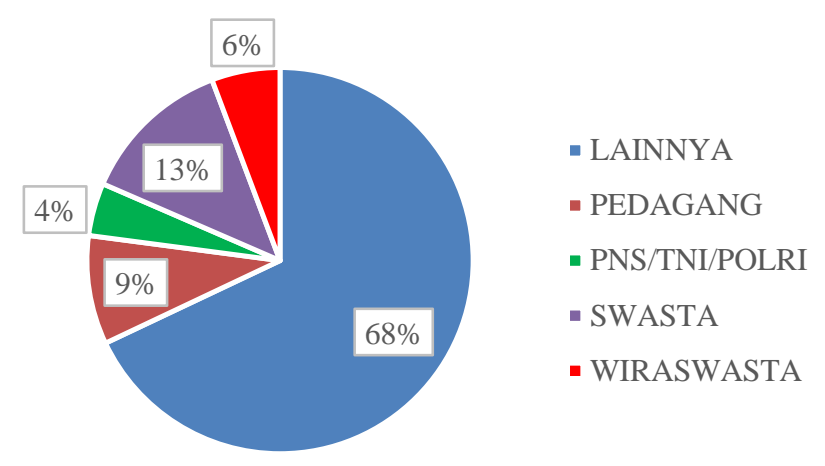

Gambar 4. Karakteristik Responden Berdasarkan Jenis Pekerjaan

\section{Hasil penelitian dengan Analisa Indeks Kepuasan Masyarakat}

Dalam menganalisa pelayanan pendidikan Kabupaten Bintan secara keseluruhan menggunakan Indeks Kepuasan Masyarakat (IKM) terlebih dahulu dilakukan penilaian kinerja pelayanan publik, menganalisa GAP digunakan untuk memetakan kesenjangan pelayanan yang diberikan dan ekspektasi atau harapan penerima layanan. Jika kualitas pelayanan yang diterima oleh konsumen tidak sesuai dengan apa yang diharapkan maka dapat terjadi kesenjangan 
pelayanan[13]. Sehingga untuk mengetahui kesenjangan tersebut, nilai rata-rata penilaian pada setiap unsur yang diberikan oleh responden dibandingkan dengan nilai maksimal sebagai nilai yang diharapkan. Tabel 3 menggambarkan parameter analisa GAP yang digunakan dalam penelitian ini.

TABEL 2

\begin{tabular}{c|c}
\multicolumn{2}{c}{ PARAMETER ANALISA GAP } \\
\hline $\begin{array}{c}\text { NILAI } \\
\text { GAP }\end{array}$ & KLASIFIKASI \\
\hline $0,00-0,50$ & Baik Sekali \\
\hline $0,50-1,00$ & Baik \\
\hline $1,01-1,150$ & Cukup \\
\hline $1,510-2,00$ & Buruk \\
\hline $2,01-4,00$ & Buruk Sekali \\
\hline
\end{tabular}

Secara keseluruhan penilaian GAP unsur-unsur Bidang Layanan Pendidikan memperoleh klasifikasi baik yang tergambar dari nilai GAP yang berada di kisaran 0,8-0,99. Untuk bidang layanan pendidikan ini, dengan nilai GAP terendah ada pada unsur biaya. Sementara untuk nilai GAP tertinggi ditempati oleh unsur perilaku pelaksana. Adanya program pendidikan gratis wajib belajar bagi anak usia sekolah dengan pendidikan wajib 9 tahun mulai dari tingkat SD sampai dengan tingkat SMP disekolah milik pemerintah mengakibatkan unsur biaya menjadi layanan terbaik dalam bidang pendidikan.

Namun program pendidikan gratis bagi siswa yang sekolah di sekolah milik pemerintah tidak mendapatkan pencapaian maksimal unsur "biaya" tertinggi dari masyarakat yaitu nilai sangat baik. Yang disinyalir akibat adanya biaya-biaya lain diluar biaya pokok yang sudah ditanggung oleh Pemerintah Kabupaten Bintan, seperti biaya alat tulis dan biaya seragam serta perlengkapan sekolah lainya. walaupun masih menempati nilai persepsi "baik", namun unsur perilaku petugas sudah mendekati batas bawah klasifikasi cukup. Hal ini menggambarkan perilaku petugas sebagai titik terlemah dalam layanan pendidikan perlu segera dibenahi. Perlu dikaji dengan lebih seksama perilaku petugas yang mana yang masih kurang memuaskan masyarakat Bintan.

TABEL 3

PENILAIAN GAP UNSUR - UNSUR BIDANG LAYANAN PENDIDIKAN

\begin{tabular}{|c|c|c|c|c|c|c|c|c|c|}
\hline Unsur Penilaian & $\begin{array}{c}\text { Kemud } \\
\text { ahan } \\
\text { Persyar } \\
\text { atan } \\
\end{array}$ & $\begin{array}{c}\text { Kesederh } \\
\text { anaan } \\
\text { Prosedur }\end{array}$ & $\begin{array}{c}\text { Kecep } \\
\text { atan } \\
\text { Pelaya } \\
\text { nan } \\
\end{array}$ & $\begin{array}{l}\text { Biaya/ } \\
\text { Tarif }\end{array}$ & $\begin{array}{l}\text { Kesesu } \\
\text { aian } \\
\text { Pelaya } \\
\text { nan } \\
\end{array}$ & $\begin{array}{l}\text { Kemam } \\
\text { puan } \\
\text { Petugas }\end{array}$ & $\begin{array}{c}\text { Peril } \\
\text { aku } \\
\text { Petug } \\
\text { as } \\
\end{array}$ & $\begin{array}{c}\text { Saran } \\
\text { a dan } \\
\text { Prasar } \\
\text { ana } \\
\end{array}$ & $\begin{array}{l}\text { Penanga } \\
\text { nan } \\
\text { Pengadu } \\
\text { an } \\
\end{array}$ \\
\hline $\begin{array}{c}\text { Nilai Rata-Rata Per } \\
\text { Unsur }\end{array}$ & 3.15 & 3.15 & 3.10 & 3.20 & 3.15 & 3.16 & 3.01 & 3.19 & 3.10 \\
\hline Nilai Diharapkan & 4.00 & 4.00 & 4.00 & 4.00 & 4.00 & 4.00 & 4.00 & 4.00 & 4.00 \\
\hline$G A P$ & 0.85 & 0.85 & 0.90 & 0.80 & 0.85 & 0.84 & 0.99 & 0.81 & 0.90 \\
\hline $\begin{array}{l}\text { Interprestasi } \\
\text { Kinerja Unsur }\end{array}$ & Baik & Baik & Baik & Baik & Baik & Baik & Baik & Baik & Baik \\
\hline $\begin{array}{c}\text { Nilai Rata-Rata Per } \\
\text { Unsur }\end{array}$ & 3.15 & 3.15 & 3.10 & 3.20 & 3.15 & 3.16 & 3.01 & 3.19 & 3.10 \\
\hline Nilai Diharapkan & 4.00 & 4.00 & 4.00 & 4.00 & 4.00 & 4.00 & 4.00 & 4.00 & 4.00 \\
\hline
\end{tabular}

Sumber: sumber diolah 2018

Setelah melakukan analisis terhadap kinerja di atas, untuk memperoleh Indeks Kepuasan Masyarakat (IKM) yaitu data dan informasi tentang tingkat kepuasan masyarakat yang berasal dari hasil pengukuran secara kuantitatif atas pendapat masyarakat dalam memperoleh pelayanan bidang pendidikan. Tabel 4 berikut ini menunjukan hasil analisis kuantitatif terhadap penilaian yang diberikan responden pada sembilan unsur pelayanan pendidikan di kabupaten Bintan. 
TABEL 4

\begin{tabular}{|c|c|c|c|}
\hline \multicolumn{4}{|c|}{ INDEKS KEPUASAN MASYARAKAT BIDANG PENDIDIKAN } \\
\hline No. & Unsur Penilaian & $\begin{array}{l}\text { Nilai Rata- } \\
\text { Rata Unsur }\end{array}$ & $\begin{array}{l}\text { Nilai Rata-Rata } \\
\text { Tertimbang }\end{array}$ \\
\hline 1. & Syarat & 3,15 & 0,34 \\
\hline 2. & Prosedur & 3,15 & 0,35 \\
\hline 3. & Waktu & 3,10 & 0,34 \\
\hline 4. & Biaya & 3,20 & 0,35 \\
\hline 5. & Kesesuain Pelayanan & 3,15 & 0,35 \\
\hline 6. & Kompetensi & 3,16 & 0,35 \\
\hline 7. & Perilaku & 3,01 & 0,33 \\
\hline & Pengaduan & & \\
\hline 8. & Kualitas Pengaduan & 3,19 & 0,35 \\
\hline 9. & Sarana dan Sarana & 3,10 & 0,34 \\
\hline Nila & & & 3,10 \\
\hline Ind & Kepuasan Masyarakat & & 77,57 \\
\hline Mu & Pelayanan & & Baik \\
\hline
\end{tabular}

Sumber: diolah Penulis :2018

Berdasarkan hasil survei kepuasan masyarakat yang dilakukan pada 384 responden pada pelayananan pendidikan diperoleh IKM layanan pendidikan dengan mengabil lokus ada layanan pada Sekolah dasar dan Sekolah di Kabupaten Bintan (kecuali Kecamatan Tambelan) diperoleh nilai IKM sebesar 77,57 dengan mutu pelayanan B atau dengan kategori (Baik).

Dari perhitungan data penelitian diatas dapat dilihat perolehan hasil kepuasan masyarakat Bintan terhadap layanan pendidikan memperoleh nilai puas dengan presentase sebesar 77,57\%. Pembahasan dari masing-masing indikator akan disajikan sebagai berikut:

\section{a. Unsur persyaratan}

Persyaratan adalah kebutuhan yang dipenuhi dalam pengurusan suatu jenis pelayanan, baik persyaratan teknis maupun administratif. Dalam survei kepuasan masyarakat dengan indikator persyaratan, mayoritas menyatakan bahwa mereka setuju bahwa persyaratan dalam layanan pendidikan mudah untuk dipenuhi. Hal tersebut ditunjukan dengan rata-rata 3,15 atau berada di interval likert

b. Unsur prosedur

Prosedur adalah tata cara pelayanan dasar bagi pemberi dan penerima pelayanan, termasuk pengaduan. Dalam survei kepuasan masyarakat dengan 384 responden, kesederhanaan prosedur layanan pendidikan di Kabupaten Bintan termasuk baik dengan nilai rata-rata 3,15 atau berada di interval likert 3 .

c. Unsur Waktu Pelayanan

Kehidupan masyarakat yang saat ini begitu komplek maka kecepatan pelayanan merupakan bagian yang diinginkan selain produk layanan. Dalam survei kepuasan masyarakat dengan 354 orang responden pengguna layanan pendidikan, waktu penyelesaian layanan pendidikan di Kabupaten Bintan termasuk baik yang ditunjukkan dengan rata-rata 3,10 atau berada di interval likert 3.

d. Unsur Biaya/Tarif

Pelayanan pendidikan merupakan kebutuhan bagi semua masyarakat dan mendapatkan perhatian bagi pemerintah pusat ataupun daerah melalui anggaran yang dialokasikan. Biaya menjadi salah satu unsur dalam mengukur kualitas pelayanan. Dalam survei kepuasan masyarakat dengan 354 orang responden pengguna layanan pendidikan, mayoritas responden setuju tidak ada pungutan diluar ketentuan tertulis dan diketahui secara luas dalam layanan pendidikan dengan nilai 3,20 atau berada di interval likert 3 .

e. Unsur Kesesuaian Layanan Produk

Hasil pelayanan yang diberikan dan diterima harus sesuai dengan ketentuan yang telah ditetapkan. Tanggapan Dalam survei kepuasan masyarakat dengan 384 responden, hasil 
pelayanan yang diterima sesuai dengan ketentuan yang telah ditetapkan pada layanan pendidikan di Kabupaten Bintan dengan nilai rata-rata 3,15 atau berada di interval likert 3.

f. Unsur Kompetensi Pelaksana

Petugas yang handal tidak hanya mampu memberikan pelayanan yang cepat, tetapi juga petugas yang mampu memanfaatkan teknologi, memahami regulasi dan kemampuan teknis lainya. Dalam survei kepuasan masyarakat dengan 354 orang responden pengguna layanan pendidikan, kompetensi petugas atau guru dianggap telah memiliki pengetahuan, keahlian, keterampilan, dan pengalaman sesuai dengan bidang tugasnya dengan nilai rata-rata 3,16 atau berada di interval likert 3 .

g. Unsur Perilaku Pelaksana

Perilaku pelaksana adalah sikap yang menunjuk pada karakteristik pada petugas dalam memberikan pelayanan. Dalam survei kepuasan masyarakat dengan 354 orang responden pengguna layanan pendidikan, rata-rata nilai perilaku pelaksana adalah 3,01. Nilai tersebut cenderung lebih rendah dari unsur lainnya, petugas layanan pendidikan dianggap belum memberikan perhatian lebih kepada penerima layanan.

h. Unsur Sarana dan Prasarana

Ketersediaan sarana dan prasarana dinilai sebagai pelayanan yang berkualitas dimana dapat memberikan kenyamanan dan keamanan bagi penerima layanan. Dalam survei kepuasan masyarakat dengan 354 orang responden pengguna layanan pendidikan, sarana dan prasana layanan pendidikan Kabupaten Bintan seperti fasilitas fisik (area parkir/ kelas/perpustakaan / ruang pelayanan lainya) yang tersedia nyaman, lengkap dan terawat dengan nilai rata-rata 3,10 atau berada di interval likert 3.

i. Unsur Penanganan Pengaduhan, Saran Masukan Penanganan pengaduan, saran dan masukan, adalah prosedur pelaksanaan terhadap laporan pengaduan, saran dan masukan dari para pengguna layanan dan mampu merespon dan/atau menindak lanjuti dengan baik dan cepat. Dalam survei kepuasan masyarakat dengan 354 orang responden pengguna layanan pendidikan, mayoritas responden terkait dengan sistem penanganan pengaduan, saran dan masukan serta kemudahan akses, memiliki alur yang jelas dan dapat ditindaklanjuti dalam layanan pendidikan kabupaten bintan dengan nilai rata-rata 3,19 atau berada di interval likert 3.

\section{KESIMPULAN DAN SARAN}

Berdasarkan hasil pembahasan, diperoleh sebuah sebuah kesimpulan bahwa Indeks Kepuasan Masyarakat Bidang Pendidikan dari seluruh unsur mencapai kategori kinerja Baik dengan Mutu (B). kontribusi GAB terlebar sebesar 0,99 dari unsur ke7 yaitu Perilaku petugas. Dengan masih sulitnya jalur transportasi di Bintan, perilaku guru sebagai Petugas layanan menjadi salah satu alasan para siswa untuk semangat dalam bersekolah, dimana guru yang langsung bersentuhan dengan masyarakat penerima layanan dan mempunyai peranan ganda yaitu sebagai pendidik dan pengajar sehingga perlu menjadi teladan dan mitra bagi siswanya dengan berhati-hativfmenjaga sikap, perilaku, penampilan, dan tutur kata dimanapun guru berada.

Pemerintah daerah, khususnya petugas layanan pendidikan, perlu meningkatkan suasana pembelajaran dan prosedur pembelajaran berjalan lebih ideal dan menarik. Dengan terbentuknya suasana belajar dan proses pembelajaran, siswa secara efektif akan mengembangkan potensi sesuai dengan minat dan bakatnya. Sehingga dengan peningkatan kemampuan spiritual keagamaan, pengendalian diri, kepribadian, kecerdasan, akhlak mulia, serta kemampuan yang dibutuhkan dirinya, masyarakat, bangsa dan Negara.

\section{UCAPAN TERIMA KASIH}

Penulis mengucapkan terima kasih kepada Dr. Adji Suradji Muhammad, M.Si selaku dosen yang senantiasa memberikan bimbingan, nasehat, dan motivasi kepada penulis serta seluruh pihak sehingga penelitian ini selesai dengan baik. 


\section{DAFTAR RUJUKAN}

\section{Buku}

[9] S. A. Salim, G. M., \& Woodward, The Manager Monitor, Rediscofav. London: McGraw-Hill Co, 1992.

[12] Djaali, Skala Likert. Jakarta: Pustaka Utama, 2008.

\section{Jurnal}

I. Apriliani, "Analisis Kepuasan Masyarakat Terhadap Penyelenggaraan Pelayanan Publik di Dinas Pendidikan, Kebudayaan, Pemuda, dan Olah Raga Kota Metro ( Studi Penyelenggaraan Peserta Didik Baru Online Tahun 2014)," Univesitas Lampung, 2015.

E. S. Maduratna, "Analisis Survei Kepuasan Masyarakat Terhadap Pelayanan Publik Di Rsud Kabupaten Sampang (Studi Deskriptif Di RSUD Kabupaten Sampang)," J. Adm. Publik, vol. 14, no. 2, pp. 197211, 2016. [4] M. Wibisono, Aryo . Arifin, "Analisis Kepuasan Masyarakat Dalam Pelayanan Publik," J. Bisnis Akunt. Vol., vol. 8, no. 2, pp. 102$111,2018$.

S. B. Raharjo, "Evaluasi Trend Kualitas Pendidikan Di Indonesia," J. Penelit. dan Eval. Pendidik., vol. 16, no. 2, pp. 513-532, 2012. [7] H. Wahyudianto, "Pengukuran Tingkat Kepuasan Masyarakat terhadap Pelaksanaan Kebijakan Pelayanan Pemerintah," $J$. Bina Praja, vol. 07, no. 04, pp. 331-345, 2015.

I. Concepción, J. Campa, R. P. Romero-galisteo, M. Teresa, L. Manzanares, and N. Moreno, "Evaluation of quality of service in Early Intervention : A systematic review $\square$," vol. 90, no. 5, 2019.

A. Coste and A. Tiron, "Service Performance - Between Measurement and Information in the Public Sector," Procedia - Soc. Behav. Sci., vol. 92, no. Lumen, pp. 215-219, 2013.

A. Zainudin and S. Sutjiatmi, "Analisis Indeks Kepuasan Masyarakat Badan Pelayanan Perizinan Terpadu Kota Tegal," JIP (Jurnal Ilmu Pemerintahan) Kaji. Ilmu
Pemerintah. dan Polit. Drh., vol. 1, no. 1, pp. 126-140, 2016.

\section{Artikel/Modul/Diktat}

"Visi dan Misi Kabupaten Bintan Kabupaten Bintan 20162021." [Online]. Available: http://sipsn.menlhk.go.id/sites/default/files/filelampiran/visi-misi/2. LEMBAR VISI DAN MISI.pdf. [Accessed: 01-Jul-2020].

\section{Peraturan Perundang-undangan}

"Undang Undang Dasar Negara Republik Indonesia Tahun 1945."

Peraturan Menteri Pendayagunaan Aparatur Negara Dan Reformasi Birokrasi Republik Indonesia Nomor 14 Tahun 2017 Tentang Pedoman Penyusunan Survei Kepuasan Masyarakat Unit Penyelenggara Pelayanan Publik, no. 708. 2017, pp. 1-30. 